Published in final edited form as:

J Clin Cell Immunol. ; 4(5): . doi:10.4172/2155-9899.1000164.

\title{
Galectins in the Pathogenesis of Rheumatoid Arthritis
}

\author{
Song $\mathrm{Li}^{1}$, Yangsheng $\mathbf{Y u}^{1}$, Christopher D Koehn ${ }^{2}$, Zhixin Zhang ${ }^{1,3}$, and Kaihong Su ${ }^{1,2,3}$ \\ ${ }^{1}$ Department of Pathology and Microbiology, University of Nebraska Medical Center, Omaha, NE \\ 68198, USA \\ 2Department of Internal Medicine, University of Nebraska Medical Center, Omaha, NE 68198, \\ USA
}

${ }^{3}$ The Eppley Cancer Institute, University of Nebraska Medical Center, Omaha, NE 68198, USA

\begin{abstract}
Rheumatoid arthritis (RA) is a complex and common systemic autoimmune disease characterized by synovial inflammation and hyperplasia. Multiple proteins, cells, and pathways have been identified to contribute to the pathogenesis of RA. Galectins are a group of lectins that bind to $\beta$ galactoside carbohydrates on the cell surface and in the extracellular matrix. They are expressed in a wide variety of tissues and organs with the highest expression in the immune system. Galectins are potent immune regulators and modulate a range of pathological processes, such as inflammation, autoimmunity, and cancer. Accumulated evidence shows that several family members of galectins play positive or negative roles in the disease development of RA, through their effects on T and B lymphocytes, myeloid lineage cells, and fibroblast-like synoviocytes. In this review, we will summarize the function of different galectins in immune modulation and their distinct roles in RA pathogenesis.
\end{abstract}

\section{Keywords}

Rheumatoid arthritis; Galectin; Inflammation; Pathogenesis; T cells; Fibroblast-like synoviocytes

\section{Introduction}

Rheumatoid arthritis (RA) is a complex and common systemic autoimmune disease, characterized by synovial inflammation and hyperplasia, cartilage and bone destruction, and extra-synovial symptoms [1]. The prevalence of RA in the adult population is estimated at $1 \%$ worldwide and is three times higher in women than in men [2]. RA principally attacks flexible joints symmetrically, progressing from distal joints to proximal joints [3]. RA inflammation can also diffuse into extra-synovial tissues and organs, leading to a higher risk of developing cardiovascular diseases, lymphoma, and lung cancer $[2,4,5]$. The diagnosis of clinical RA is based on several criteria, including physical symptoms, joint radiographs, and serological tests [6]. Treatment strategies for RA patients include non-steroidal antiinflammatory drugs (NSAIDs), disease-modifying anti-rheumatic drugs (DMARDs), and biological agents, such as blocking antibodies for tumor necrosis factor alpha (TNFa) and interleukin-6 (IL-6) [2]. Although these drugs can relieve symptoms and delay disease progression, none of them provide a cure for RA nor have consistent efficacy in all patients.

Copyright: () $2013 \mathrm{Li}$ S, et al.

*Corresponding author: Kaihong Su, Ph.D., Associate Professor, Department of Pathology and Microbiology, University of Nebraska Medical Center, LTC 11724, 987660 Nebraska Medical Center, Omaha, NE 68198-7660, USA, Tel: 402-559-7612; Fax:

402-559-7716; ksu@unmc.edu. 
The etiology of RA involves a complex interplay of multiple proteins, cells, and pathways. Among those, galectins have recently emerged as an important group of proteins which modulate immune activation and inflammation [7]. Galectins are the lectin family members that bind to $\beta$-galactoside carbohydrates. They are widely expressed in different tissues and organs with the highest expression patterns in the immune system [8]. Through binding to their receptors, galectins mediate fundamental intra- and inter-cellular signaling as well as cell-extracellular matrix (ECM) interactions [8]. As potent immune regulators, galectins play an important role in a number of pathological processes including inflammation, autoimmunity, fibrosis, and cancer [7].

In this review, we will summarize the current understanding of the role of different galectins in RA, based on a comprehensive literature review of published empirical research. The electronic databases of Pubmed/Medline, Embase, EBSCO, SCOPUS, and Cochrane Library were searched using key words "arthritis" and "galectin" in all fields to the cut-off date of September 16, 2013. Over 100 manuscripts in English language were identified in the search. Among those, thirty research manuscripts and one conference abstract provide direct evidence regarding the pathogenic role and therapeutic potential of galectins in RA (Table 1). Herein, we will briefly review the pathogenic mechanisms of RA and discuss in detail the role of different galectins in RA pathogenesis and therapeutics.

\section{Pathogenesis of RA}

Although RA was first described more than 200 years ago, its etiology has not been completely characterized. Both genetic and environmental factors contribute to the development of RA. To date, more than 30 gene loci have been found to contribute to RA susceptibility and disease severity [9-11]. Many of those gene loci are related to immune cell activation, such as MHC class I allele HLA-DRB1 and gene variants of cytotoxic T lymphocyte-associated antigen-4 (CTLA-4) and proteintyrosine-phosphatase nonreceptor type 22 (PTPN22). Environmental risk factors include bacterial and viral infections, smoking, and alcohol consumption [11,12]. Gene-environment interactions can also synergistically increase the risk of developing RA in certain subgroups of people. For example, a combination of smoking and the HLA-DRB1 allele increases the risk for RA by 21-fold in the anti-cyclic citrullinated peptide antibody (ACPA) positive population [13].

A major characteristic of RA is the infiltration of multiple leukocytes into the joints, including B cells, T cells, macrophages, dendritic cells, and neutrophils. Infiltrated leukocytes form ectopic germinal centers and drive adaptive immune responses in the RA joints. B cells can locally produce autoantibodies, including ACPA [14,15]. T cells play a central role in mediating joint damage by driving the activation of other effector cells $[16,17]$. Although $\mathrm{CD}^{+} \mathrm{T}$ cells are the dominant $\mathrm{T}$ cell types in the synovium, Th17, a subset of T helper cells secreting IL-17, and regulatory T cells (Treg) also play a critical role in RA pathogenesis $[18,19]$. Neutrophils are the most abundant leukocytes in RA synovial fluid (SF) [20]. In RA patients, SF neutrophils remain active for an overly extended length of time [21,22]. Activated neutrophils release proteolytic enzymes, reactive oxygen species (ROS), and neutrophil extracellular trap (NET), which can damage local tissues as in other autoimmune diseases [23]. Neutrophils also secrete pro-inflammatory cytokines such as TNFa, IL-1 and IL-6, as well as chemokines to further amplify joint inflammation [24]. Macrophages, derived from circulating monocytes or local macrophage-like synoviocytes, provide another main source of pro-inflammatory cytokines [25]. In addition, synovial macrophages in RA strongly express MHC class II and are potent for antigen presenting and T cell activation [16]. 
Another characteristic of RA is the activation of local fibroblast-like synoviocytes (FLS) [26]. In RA joints, resident FLS show a transformed phenotype with over-expressed protooncogenes and defective cell death pathways. FLS in RA secret a wide range of proinflammatory cytokines and chemotactic proteins and also express surface ligands for interacting with immune cells [27]. In addition, RA FLS release proteolytic enzymes such as matrix metalloproteinases (MMP), cathepsins, and plasmins. Thus, it has been suggested that FLS are the main cells responsible for the invasion and destruction of cartilage and bones, promotion of angiogenesis, and facilitation of osteoclastogenesis [27].

Besides the cells mentioned above, numerous proteins have been shown to play a role in RA pathogenesis. Some of them have been successfully adapted in clinical diagnosis and therapies for RA, such as ACPA, TNFa, IL-1, and IL-6 [2]. The family of galectins is involved in a wide range of biological processes. Their immune modulating role has drawn an increasing attention in the field of arthritis research. Our discussion will now turn to the function of galectins and their potential role in RA pathogenesis and therapies.

\section{The Family of Galectins}

Galectins are a group of lectins that specifically bind to $\beta$-galectoside carbohydrates and share significant sequence similarity in their carbohydrate-recognition domains (CRDs) [8]. The galectin genes are evolutionarily conserved and can be found in many organisms, including viruses, sponges, fungi, plants, nematodes, insects, and vertebrates [8]. Currently there are at least 15 mammalian galectins, all of which contain one or two CRDs of about 130 amino acids each. Based on the CRD organization, galectins are divided into three subfamilies (Figure 1, panel A). Galectin-1, -2, -5, -7, -10, -11, -13, and -14 contain only one CRD and are classified as the "proto type". In contrast, the "tandem-repeat type" (galectin-4, $-6,-8,-9$, and -12) have two separate CRDs connected by non-conserved amino acid sequences. Galectin-3 is the only member of the "chimeric type" and contains one CRD and a non-lectin region of about 120 residues at the N-terminal of CRD [8]. Some galectins can self-dimerize or oligomerize, forming bivalent or multivalent complexes for stronger signaling [28,29] (Figure 1, panel A).

Galectins have been detected in numerous tissues and organs. Their distributions can be ubiquitous (e.g. galectin-1, $-3,-8$ and -9 ) or limited to specific tissue types (e.g. galectin-2 and -4) [30]. Due to the absence of the classical signal sequence for insertion into the endoplasmic reticulum (ER), galectins primarily localize intracellularly [31]. However, some types of galectins can be found on the cell surface (e.g. galectin-9) or secreted through a non-classical ER/Golgi-independent pathway to the extracellular compartment (e.g. galectin-1 and -3) [32,33].

\section{Function of Galectins}

The sugar-binding specificity and affinity vary among different members of the galectin family, implicating their specialized and diversified functions [34]. Each galectin recognizes a set of glycoproteins with a particular oligosaccharide sequence. The variety of binding partners and wide distribution of galectins allow them to function in multiple biological reactions, including mRNA splicing (e.g. galectin-1 and -3) [35,36], cell apoptosis (e.g. galectin-3, 7,-9,-12) [37-39], cell cycle regulation (e.g. galectin-3 and -12) [40,41], cell activation (e.g. galectin-3) [42,43], cell adhesion and migration (e.g. galectin-1, $-2,-3,-4,-8$ and -9) [44], and cell differentiation (e.g. galectin-3, -9, -10) [45]. Pathologically, galectins have been linked to a number of diseases including cancer, cardiovascular disease, liver fibrogenesis, asthma, and RA [7]. 
The role of galectins in RA varies among different members of the galectin family as different galectins can positively or negatively regulate immune responses and inflammatory reactions. To date, multiple studies have identified a regulatory role of galectin-1, -3 , and -9 in RA while only a few studies suggested a role of galectin-2 and -8 in RA. We will now discuss each of the five types of galectins regarding to their potential function in RA.

\section{Galectin-1 in RA \\ Overview of galectin-1}

Galectin-1 is a "proto type" galectin and can form homodimers by cross-linking [46,47]. It is highly expressed by immune-related cells such as lymphoid stromal cells, macrophages [48], T cells [49], and endothelial cells [50]. In most studies, galectin-1 has been shown to be immunosuppressive and anti-inflammatory. The main receptors of galectin- 1 on the T cell surface are CD43 and CD45 [51,52]. Through surface receptor binding, galectin-1 regulates negative selection of $\mathrm{T}$ cells in the thymus [51,53], induces Th1 and Th17 cell apoptosis [54], and promotes the shift from Th1 to Th2 polarized immune responses [55]. Treatment of $\mathrm{T}$ cells with galectin- 1 changes the cytokine profile, with decreased pro-inflammatory cytokines such as TNFa, IL-1 $\beta$, IL-2, and IFN $\gamma[56,57]$ and increased anti-inflammatory cytokines such as IL-10 [58]. For B cells, galectin-1 negatively regulates cell proliferation and BCR-mediated signal transduction [59]. Galectin-1 also regulates innate immune cell activation. Treatment of galectin-1 dramatically reduced neutrophil infiltration, mast cell degranulation [60], and inducible nitric oxide synthase (iNOS) expression in macrophages [61]. The anti-inflammatory activity of galectin- 1 has also been suggested in various experimental models of inflammatory or autoimmune diseases including experimental autoimmune uveitis [62], myasthenia gravis [63], graft-versus-host disease [64], experimental autoimmune encephalomyelitis [65], experimental colitis [66], diabetes [67], concanavalin A-induced hepatitis [68], and collagen-induced arthritis [55].

\section{Galectin-1 in arthritis animal models}

The link between galectin-1 and RA was first reported by Rabinovich et al. in 1999 using collagen-induced arthritis (CIA) mouse model [55]. A single injection of fibroblasts engineered to secrete mouse galectin-1 or daily administration of $100 \mu \mathrm{g}$ of recombinant human galectin-1 in DBA/1 mice was sufficient to suppress the overall clinical and histopathological manifestations of CIA [55]. Galectin-1 treatment also reduced the anticollagen antibody levels and skewed the cytokine profile toward a type-2 polarized immune reaction [55]. Further investigation into the mechanism revealed that galectin-1 treatment enhanced the susceptibility of T cells to antigen-induced apoptosis, increased T cell adhesion to extracellular matrix, and also inhibited IL-2 secretion from collagen-specific $\mathrm{T}$ cell hybridomas [54,56,57]. In addition, galectin-1 functions to limit neutrophil recruitment to TNF-treated endothelium; and leukocyte adhesion and emigration were significantly increased in galectin-1-deficient mice inflamed with IL-1 $\beta$ [69]. In a more recent study, galectin-1-deficient mice exhibited increased susceptibility to CIA, with earlier onset of arthritis and more severe manifestations than the wild type mice [70]. These studies further demonstrated the inhibitory function of galectin-1 in the development of arthritis and the disease severity in animal models.

\section{Galectin-1 in RA patients}

In human patients, in situ immunohistochemistry showed remarkably reduced expression of galectin-1 in synovial tissue from patients with long duration of juvenile idiopathic arthritis (JIA) [71]. Reduced expression of galectin-1 may lead to defective mononuclear cell apoptosis in JIA patients [71]. Furthermore, expression of galectin-1 has never been found at the sites of cartilage invasion in RA [72,73]. Although the plasma levels of galectin-1 are 
comparable between RA patients and healthy controls, concentration of galectin- 1 in synovial fluid (SF) is significantly decreased [74]. The reduced SF galectin-1 levels correlate to the increased levels of anti-galectin- 1 autoantibodies and anti-cyclic citrullinated peptide (CCP) antibodies in RA patients [74]. These clinical studies confirmed the potential involvement of galectin-1 in RA pathogenesis, and provided a rational for using synovial galectin-1 as a biomarker for RA prognosis.

\section{Therapeutic potential of galectin-1}

Based on the immunomodulatory effects of galectin-1 in RA, there has been much interest in designing galectin-1 derivatives as anti-RA drugs. In one study, intra-articular lentiviral vectors encoding galectin-1 were injected into rats with CIA [75]. This treatment significantly ameliorated CIA, measured by articular index, radiographic, and histological scores; T-cell infiltrates; and microvessel density in the ankle joints [75]. High frequencies of antigen-induced $\mathrm{T}$ cell apoptosis were also noticed in the lymph nodes of treated rats [75]. However, the anti-RA activities of galectin-1 require concentrations higher than $7 \mu \mathrm{M}$ to allow formation of galectin-1 homodimers [76,77]. To overcome this limitation, galectin-1 was conjugated onto gold nanoparticles (Au-Gal1) to form a multivalent structure [78]. AuGal1 provided enhanced stability and biological activity, and showed better therapeutic effects than free galectin-1 in vitro and in vivo. In another study, a chimeric protein was genetically engineered by fusing galectin-1 to the $\mathrm{Fc}$ region of human IgG1 (Gal-1hFc) [79]. Gal- $1 \mathrm{hFc}$ is stable and always dimeric, thus the molecule is biologically functional at low concentrations. Investigation of Gal-1hFc's effects on leukocytic infiltrates in RA synovial fluids showed that $94 \%$ of leukocytes expressed galectin-1 receptor and were susceptible to Gal-1hFc-mediated cell death, revealing the potency of this chimeric protein for RA treatment. Furthermore, a recent study showed that low concentrations of galectin-1 can induce chondrogenic differentiation of mesenchymal stem cells (MSCs) from RA bone marrow [80], suggesting a potential application of galectin-1 in cartilage transplantation treatment for RA.

In summary, galectin-1 plays an inhibitory role in the development of experimental arthritis mainly through the induction of $\mathrm{T}$ cell apoptosis and skewed type-2 cytokine response. In human patients, the expression levels of galectin-1 were significantly down-regulated in the synovium of RA and JIA patients and the downregulation of galectin- 1 was correlated with the increased anti-CCP titers. In pre-clinical animal studies, administration of galectin- 1 or its derivatives ameliorated the antigen-induced arthritis, providing a strong rational for using galectin-1 as anti-RA drugs in the future.

\section{Galectin-3 in RA}

\section{Overview of galectin-3}

While galectin-1 is a negative regulator of autoimmunity in RA, galectin-3 promotes inflammation in RA. Galectin-3 is the only chimeric type of galectin. It has a long Nterminal domain with proline-and glycine-rich repeats connected to one CRD [81]. The Nterminal domain, which is $34 \%$ homologous to the collagen- 1 chain, is responsible for selfoligomerization, and thus is essential for its biological activity [81]. Galectin-3 exists as monomer in solution, and self-assembles into higher order oligomers in the presence of multivalent carbohydrate ligands [82].

Functionally, galectin-3 is also known as epsilon BP for its IgE-binding activity and as Mac-2, a macrophage surface antigen [81]. By cross-linking cell surface receptors, galectin-3 activates several types of lymphoid and myeloid cells. It increases IL-2 production in T cells [83] and promotes IgE production in B cells [84]. For myeloid-linage 
cells, galectin-3 stimulates superoxide release from neutrophils and monocytes [43], potentiates IL-1 production by monocytes [85], and induces 5-hydroxytryptamine (5-HT) release from mast cells [86] and basophils [86,87]. In addition, galectin-3 can bridge cells and the ECM to promote chemo-attraction and retention of macrophages [88] and neutrophils [89]. In line with its in vitro pro-inflammatory function, it has been shown that the levels of galectin- 3 are elevated in the serum or nidi of patients with inflammatory diseases including RA [72], systemic lupus erythematosus (SLE) [90], Behçet's disease [91], and systemic sclerosis [92].

\section{Galectin-3 in arthritis animal models}

Studies with CIA rats found increased galectin-3 secretion into the plasma over time, which correlated with the disease progression, implicating that galectin-3 promotes the development of experimental arthritis [93]. Recent studies with galectin-3-deficient mice further confirmed the stimulating role of galectin-3 in arthritis [94]. The joint inflammation and bone erosion of antigen-induced arthritis were markedly suppressed in galectin-3deficient mice as compared with the wild type mice [94]. The reduced arthritis in galectin-3deficient mice was accompanied by decreased levels of antigen-specific IgG and proinflammatory cytokines including TNFa, IL-6, and IL-17 [94]. Furthermore, an exogenous supply of recombinant galectin-3 restored the reduced arthritis and cytokine production in galectin-3-deficient mice [94]. This study provided the direct evidence that galectin-3 plays a crucial role in the development of arthritis in animal models.

\section{Galectin-3 in RA patients}

In human patients, galectin-3 was detected in the synovial tissue of RA and JIA patients, with clear accumulation at the sites of cartilage invasion [71,72,95-97]. The serum levels of galectin-3 were elevated in patients with RA, JIA, Behçet's disease, or systemic sclerosis $[72,91,92,98]$. Although the increased galectin-3 is not specific for RA, the serum levels of galectin-3 were significantly associated with the C-reactive protein (CRP) levels and the disease activity scores in patients with JIA, suggesting that galectin-3 may be utilized as a biomarker for the disease progression of JIA [98]. In addition, the galectin-3 gene allele (LGALS3 +292C) is more prevalent in RA patients than in healthy controls, indicating that genetic polymorphisms of galectin-3 may influence the susceptibility to RA [99].

In addition to immune cells, FLS in the synovium of RA patients also express galectin-3 at high levels [72,73,95]. While floating FLS only express low levels of galectin-3 [95], adhesion of FLS to cartilage components through CD51/CD61 induces galectin-3 expression [100]. In RA patients, about 39\% of FLS are cartilage-adhering cells, which is four times more than in osteoarthritis (OA) patients. The increased numbers of adhering FLS contribute to the elevated galectin-3 levels in the RA synovium [100]. Moreover, galectin-3 can induce rheumatoid FLS to secret a set of pro-inflammatory cytokines and chemokines including IL-6, granulocyte-macrophage colony-stimulating factor (GMCSF), TNF, CXCL8, CCL2, CCL3, and CCL5 [101]. The induction of cytokines and chemokines by galectin-3 appears to involve different signaling pathways. The MAPK-ERK pathway was necessary for cyotokine IL-6 production, while phosphatidylinositol 3-kinase (PI3K) was required for chemokine CCL5 induction [101]. These studies using human materials further suggest a promotional role of galectin-3 in the pathogenesis of RA.

\section{Therapeutic potential of galectin-3}

In concordance with the human and animal studies discussed above, silencing of galectin-3 expression by intra-articular injections of shRNA into rat ankle joints ameliorated the manifestation of CIA, suggesting that downregulation of galectin-3 may be a therapeutic strategy for RA [75]. In addition, using FLS derived from the synovium of RA patients, it 
has been reported that downregulation of galectin-3 expression by galectin-3 siRNA inhibited spontaneous and LPS-induced secretion of inflammatory cytokine IL-6, further suggesting the potential of targeting galectin-3 in the suppression of joint inflammation [102].

Overall, galectin-3 acts as a positive regulator for inflammation by stimulating proinflammatory cytokine/chemokine production and potentiating myeloid linage cell activation. In animal models, galectin-3 aggravates antigen-induced arthritis. In patients with RA and JIA, the levels of galectin- 3 are increased in both serum and synovium. Thus, galectin-3 blockade may provide a novel strategy for the treatment of RA.

\section{Galectin-9 in RA \\ Overview of galetin-9}

Like galectin-1, galectin-9 is anti-inflammatory, as suggested by studies in several disease animal models including CIA [103,104], asthma [105], nephrotoxic serum nephritis [106], diabetic nephropathy [107], and autoimmune encephalitis [108]. Galectin-9 contains two distinct CRDs connected by a linker peptide [109]. Three isoforms of galectin-9 have been reported which differ in the length of the linker peptide: short type (311 AAs), medium type (323 AAs), and long type (355 AAs). Galectin-9 can also form stable dimers or multimers to induce stronger signals [110]. Galectin-9 is expressed by T cells, macrophages, endothelial cells, and fibroblasts and plays an important role in regulating inflammation and immune responses [111-113].

Galectin-9 negatively regulates pro-inflammatory $\mathrm{T}$ cell responses. An important cell surface receptor for galectin-9 is T cell immunoglobulin and mucin-domain-containingmolecule- 3 (Tim-3). Tim- 3 is specifically expressed on $\mathrm{CD}^{+}{ }^{+} \mathrm{Th} 1$ cells, $\mathrm{CD} 8^{+}$cytotoxic $\mathrm{T}$ cells, and $\mathrm{CD} 11 \mathrm{~b}^{+}$dendritic cells (DC), but not on Th2 cells or macrophages [114-116]. The galectin-9-Tim-3 pathway induces apoptosis of $\mathrm{CD} 4^{+} \mathrm{Th} 1$ and $\mathrm{CD} 8^{+}$cytotoxic $\mathrm{T}$ cells. Blockade of this interaction in vivo results in exacerbated autoimmunity and abrogation of self-tolerance in animal models [117]. Galectin-9 also regulates T cell subset differentiation in vitro and in vivo. In cell culture, treatment with galectin-9 induced the differentiation of naïve $\mathrm{T}$ cells to regulatory $\mathrm{T}$ cells (Treg) and suppressed the differentiation of Th17 cells [103].

\section{Galectin-9 in arthritis animal models}

In mouse models, galectin- 9 deficiency led to increased numbers of Th1 and Th17 cells and decreased numbers of Treg cells in the joint, rendering susceptibility to CIA [103]. Conversely, subcutaneous and intraperitoneal delivery of the human stable galectin-9 recombinant proteins decreased the production of proinflammatory cytokine and suppressed the disease symptoms in the CIA mice [103]. Another study by the same group demonstrated that treatment with human stable galectin-9 induced apoptosis of cells in the joints of CIA mice and SCID mice implanted with RA patient synovial tissues [103,104]. Furthermore, galectin- 9 was shown to negatively regulate macrophage activation by increasing the expression of immunoinhibitory FcRIIb and decreasing the expression of immunoactivating FcRIII, leading to the suppression of arthritis in an immune complexinduced arthritis mouse model [118].

\section{Galectin-9 in RA patients}

Using a cell culture system, stable galectin-9 protein preferentially induced apoptosis and suppressed the proliferation of RA patient-derived FLS $[103,104]$. In RA patients, decreased galectin-9-Tim-3 signaling has been observed. The levels of Tim-3 expression on CD4 ${ }^{+} \mathrm{T}$ 
cells from RA patients were lower compared to those from healthy controls, leading to blunted galectin-9-mediated apoptosis of $\mathrm{CD}^{+} \mathrm{T}$ cells $[119,120]$. Another study showed that galectin-9 mRNA expression levels in peripheral blood mononuclear cells (PBMCs) were significantly lower in RA patients with moderate to high disease activity than those with low disease activity [104,119], implicating that galectin-9 may prevent the disease progression of RA.

\section{Therapeutic potential of galectin-9}

As discussed in the section of galectin-9 in arthritis animal models, administration of human stable recombinant galectin-9 ameliorated arthritis in CIA and an immune complex-induced arthritis mouse model, assessed by pannus formation, inflammatory cell infiltration, and bone/cartilage destruction [103,104]. These studies warrant the development of galectin-9 derivatives with enhanced in vivo stability and efficacy for the treatment of RA.

Taken together, galectin-9 is a negative regulator of arthritis as suggested by both animal and human studies. Galectin-9 plays a key role in T cell differentiation through the galectin-9-Tim-3 pathway. Galectin-9 induces the differentiation of naïve T cells to Treg cells and suppresses the differentiation of proinflammatory Th17 cells. In addition, galectin-9 induces apoptosis of FLS which may prevent synoviocyte hyperproliferation in RA joints. Therefore, up-regulation of galectin-9 and galectin-9-Tim-3 pathway is a promising strategy for the treatment of RA.

While galectin-1, 3, and 9 has been extensively studied regarding their modulating role in inflammation and arthritis, galectin- 2 and -8 have been less studied in these aspects. Only a few reports revealed the linkage of galectin -2 and -8 with RA. In the following, we will briefly summarize these findings.

\section{Galectin-2 in RA}

Galectin-2 is structurally similar to galectin-1, but has a distinct expression profile which is primarily confined to the gastrointestinal tract [121]. Like galectin-1, galectin-2 induces T cell apoptosis and suppressed colitis in a mouse model [122]. A human genetic study showed that galectin-2 3279C/T gene polymorphism may be independently associated with diastolic blood pressure in patients with RA [123]. These studies indicate that galectin-2 may play a suppressive role in RA, but more confirmative evidence is needed to support this notion.

\section{Galectin-8 in RA}

Galectin-8 is a modulator of cell adhesion and cell growth [124]. The soluble form of galectin- 8 was detected in the synovium of RA patients at the concentration that can induce apoptosis of synoviocytes [125]. However, the galectin-8-mediated apoptosis of synoviocytes was neutralized by free CD44vRA, a CD44 variant prevalent in RA SF [125]. In another study, function-blocking autoantibodies against galectin- 8 were detected in a small percentage (about 20\%) of RA patients [126,127]. The blockade of galectin- 8 function in RA patients suggests that galectin- 8 may play a suppressive role in RA. The potential role of galectin-8 in RA was further supported by a human association study. A single nucleotide polymorphism of galectin- 8 that substitutes tyrosine for phenylalanine at position 18 was shown to be more prevalent in RA patients; and also associate with the early onset of RA in a large cohort [128]. 


\section{Conclusion}

RA is a systemic autoimmune disease that involves a complex interplay of a variety of immune-modulating proteins [1]. Increasing amounts of evidence suggest that individual galectins, including galectin-1,-2, $-3,-8$, and -9 , could play positive or negative roles in the pathogenesis of RA. Manipulation of certain types of galectins can suppress or aggravate the disease symptoms in arthritis animal models, indicating the therapeutic potential of galectins for the treatment of RA. Several anti-galectin compounds are under phase 1 or 2 clinical trials for the treatment of fibrosis and cancer. Although there are no ongoing clinical trials targeting galectins for the treatment of RA, we hope that galectin-related anti-inflammatory therapies will be developed in the future as we continue to unravel the specific immunomodulatory functions of individual galectins.

\section{Acknowledgments}

Research reported in this publication was supported in part by National Institutes of Health Grants AR059351 (to K.S.), AR048592, AI073174, AI074948, and AI076475 (to Z.Z.) and by a Research Support Fund grant from the Nebraska Medical Center and the University of Nebraska Medical Center (to K.S.). The content is solely the responsibility of the authors and does not necessarily represent the official views of the National Institutes of Health.

\section{References}

1. McInnes IB, Schett G. The pathogenesis of rheumatoid arthritis. N Engl J Med. 2011; 365:22052219. [PubMed: 22150039]

2. Scott DL, Wolfe F, Huizinga TW. Rheumatoid arthritis. Lancet. 2010; 376:1094-1108. [PubMed: 20870100]

3. Khurana R, Berney SM. Clinical aspects of rheumatoid arthritis. Pathophysiology. 2005; 12:153165. [PubMed: 16125918]

4. Cojocaru M, Cojocaru IM, Silosi I, Vrabie CD, Tanasescu R. Extra-articular Manifestations in Rheumatoid Arthritis. Maedica (Buchar). 2010; 5:286-291. [PubMed: 21977172]

5. Westlake SL, Colebatch AN, Baird J, Kiely P, Quinn M, et al. The effect of methotrexate on cardiovascular disease in patients with rheumatoid arthritis: a systematic literature review. Rheumatology (Oxford). 2010; 49:295-307. [PubMed: 19946022]

6. Aletaha D, Neogi T, Silman AJ, Funovits J, Felson DT, et al. 2010 rheumatoid arthritis classification criteria: an American College of Rheumatology/European League Against Rheumatism collaborative initiative. Ann Rheum Dis. 2010; 69:1580-1588. [PubMed: 20699241]

7. Klyosov, AA.; Traber, PG. Galectins and disease implications for targeted therapeutics. OUP; USA: 2012.

8. Cooper DN, Barondes SH. God must love galectins; he made so many of them. Glycobiology. 1999; 9:979-984. [PubMed: 10521533]

9. Stahl EA, Raychaudhuri S, Remmers EF, Xie G, Eyre S, et al. Genome-wide association study meta-analysis identifies seven new rheumatoid arthritis risk loci. Nat Genet. 2010; 42:508-514. [PubMed: 20453842]

10. Barton A, Worthington J. Genetic susceptibility to rheumatoid arthritis: an emerging picture. Arthritis Rheum. 2009; 61:1441-1446. [PubMed: 19790122]

11. Plenge RM. Recent progress in rheumatoid arthritis genetics: one step towards improved patient care. Curr Opin Rheumatol. 2009; 21:262-271. [PubMed: 19365266]

12. Hitchon CA, El-Gabalawy HS. Infection and rheumatoid arthritis: still an open question. Curr Opin Rheumatol. 2011; 23:352-357. [PubMed: 21532483]

13. Klareskog L, Stolt P, Lundberg K, Källberg H, Bengtsson C, et al. A new model for an etiology of rheumatoid arthritis: smoking may trigger HLA-DR (shared epitope)-restricted immune reactions to autoantigens modified by citrullination. Arthritis Rheum. 2006; 54:38-46. [PubMed: 16385494] 
14. Snir O, Widhe M, Hermansson M, von Spee C, Lindberg J, et al. Antibodies to several citrullinated antigens are enriched in the joints of rheumatoid arthritis patients. Arthritis Rheum. 2010; 62:4452. [PubMed: 20039432]

15. Amara K, Steen J, Murray F, Morbach H, Fernandez-Rodriguez BM, et al. Monoclonal IgG antibodies generated from joint-derived B cells of RA patients have a strong bias toward citrullinated autoantigen recognition. J Exp Med. 2013; 210:445-455. [PubMed: 23440041]

16. Brennan F, Foey A. Cytokine regulation in RA synovial tissue: role of T cell/macrophage contactdependent interactions. Arthritis Res. 2002; 4(Suppl 3):S177-S182. [PubMed: 12110137]

17. Schurigt U, Pfirschke C, Irmler IM, Hückel M, Gajda M, et al. Interactions of T helper cells with fibroblast-like synoviocytes: up-regulation of matrix metalloproteinases by macrophage migration inhibitory factor from both Th1 and Th2 cells. Arthritis Rheum. 2008; 58:3030-3040. [PubMed: 18821693]

18. Kotake S, Udagawa N, Takahashi N, Matsuzaki K, Itoh K, et al. IL-17 in synovial fluids from patients with rheumatoid arthritis is a potent stimulator of osteoclastogenesis. J Clin Invest. 1999; 103:1345-1352. [PubMed: 10225978]

19. Chabaud M, Durand JM, Buchs N, Fossiez F, Page G, et al. Human interleukin-17: A T cellderived proinflammatory cytokine produced by the rheumatoid synovium. Arthritis Rheum. 1999; 42:963-970. [PubMed: 10323452]

20. Edwards SW, Hallett MB. Seeing the wood for the trees: the forgotten role of neutrophils in rheumatoid arthritis. Immunol Today. 1997; 18:320-324. [PubMed: 9238834]

21. Nathan C. Neutrophils and immunity: challenges and opportunities. Nat Rev Immunol. 2006; 6:173-182. [PubMed: 16498448]

22. Bell AL, Magill MK, McKane R, Irvine AE. Human blood and synovial fluid neutrophils cultured in vitro undergo programmed cell death which is promoted by the addition of synovial fluid. Ann Rheum Dis. 1995; 54:910-915. [PubMed: 7492241]

23. Yu Y, Su K. Neutrophil Extracellular Traps and Systemic Lupus Erythematosus. J Clin Cell Immunol. 2013; 4:139.10.4172/2155-9899.1000139 [PubMed: 24244889]

24. Cascão R, Rosário HS, Souto-Carneiro MM, Fonseca JE. Neutrophils in rheumatoid arthritis: More than simple final effectors. Autoimmun Rev. 2010; 9:531-535. [PubMed: 20060506]

25. Kinne RW, Stuhlmüller B, Burmester GR. Cells of the synovium in rheumatoid arthritis. Macrophages. Arthritis Res Ther. 2007; 9:224. [PubMed: 18177511]

26. Müller-Ladner U, Ospelt C, Gay S, Distler O, Pap T. Cells of the synovium in rheumatoid arthritis. Synovial fibroblasts. Arthritis Res Ther. 2007; 9:223. [PubMed: 18177509]

27. Karouzakis E, Neidhart M, Gay RE, Gay S. Molecular and cellular basis of rheumatoid joint destruction. Immunol Lett. 2006; 106:8-13. [PubMed: 16824621]

28. Sacchettini JC, Baum LG, Brewer CF. Multivalent protein-carbohydrate interactions. A new paradigm for supermolecular assembly and signal transduction. Biochemistry. 2001; 40:30093015. [PubMed: 11258914]

29. Ahmad N, Gabius HJ, André S, Kaltner H, Sabesan S, et al. Galectin-3 precipitates as a pentamer with synthetic multivalent carbohydrates and forms heterogeneous cross-linked complexes. J Biol Chem. 2004; 279:10841-10847. [PubMed: 14672941]

30. Chiariotti L, Salvatore P, Frunzio R, Bruni CB. Galectin genes: regulation of expression. Glycoconj J. 2004; 19:441-449. [PubMed: 14758067]

31. Wang JL, Gray RM, Haudek KC, Patterson RJ. Nucleocytoplasmic lectins. Biochim Biophys Acta. 2004; 1673:75-93. [PubMed: 15238251]

32. Hughes RC. Secretion of the galectin family of mammalian carbohydrate-binding proteins. Biochim Biophys Acta. 1999; 1473:172-185. [PubMed: 10580137]

33. Nickel W. Unconventional secretory routes: direct protein export across the plasma membrane of mammalian cells. Traffic. 2005; 6:607-614. [PubMed: 15998317]

34. Hirabayashi J, Hashidate T, Arata Y, Nishi N, Nakamura T, et al. Oligosaccharide specificity of galectins: a search by frontal affinity chromatography. Biochim Biophys Acta. 2002; 1572:232254. [PubMed: 12223272]

35. Dagher SF, Wang JL, Patterson RJ. Identification of galectin-3 as a factor in pre-mRNA splicing. Proc Natl Acad Sci U S A. 1995; 92:1213-1217. [PubMed: 7862663] 
36. Vyakarnam A, Dagher SF, Wang JL, Patterson RJ. Evidence for a role for galectin-1 in pre-mRNA splicing. Mol Cell Biol. 1997; 17:4730-4737. [PubMed: 9234729]

37. Kuwabara I, Kuwabara Y, Yang RY, Schuler M, Green DR, et al. Galectin-7 (PIG1) exhibits proapoptotic function through JNK activation and mitochondrial cytochrome c release. J Biol Chem. 2002; 277:3487-3497. [PubMed: 11706006]

38. Hotta K, Funahashi T, Matsukawa Y, Takahashi M, Nishizawa H, et al. Galectin-12, an Adiposeexpressed Galectin-like Molecule Possessing Apoptosis-inducing Activity. J Biol Chem. 2001; 276:34089-34097. [PubMed: 11435439]

39. Wada J, Ota K, Kumar A, Wallner EI, Kanwar YS. Developmental regulation, expression, and apoptotic potential of galectin-9, a beta-galactoside binding lectin. J Clin Invest. 1997; 99:24522461. [PubMed: 9153289]

40. Kim HR, Lin HM, Biliran H, Raz A. Cell cycle arrest and inhibition of anoikis by galectin-3 in human breast epithelial cells. Cancer Res. 1999; 59:4148-4154. [PubMed: 10463621]

41. Yang RY, Hsu DK, Yu L, Ni J, Liu FT. Cell cycle regulation by galectin-12, a new member of the galectin superfamily. J Biol Chem. 2001; 276:20252-20260. [PubMed: 11283015]

42. Liu FT, Hsu DK, Zuberi RI, Kuwabara I, Chi EY, et al. Expression and function of galectin-3, a beta-galactoside-binding lectin, in human monocytes and macrophages. Am J Pathol. 1995; 147:1016-1028. [PubMed: 7573347]

43. Yamaoka A, Kuwabara I, Frigeri LG, Liu FT. A human lectin, galectin-3 (epsilon bp/Mac-2), stimulates superoxide production by neutrophils. J Immunol. 1995; 154:3479-3487. [PubMed: 7897228]

44. Elola MT, Wolfenstein-Todel C, Troncoso MF, Vasta GR, Rabinovich GA. Galectins: matricellular glycan-binding proteins linking cell adhesion, migration, and survival. Cell Mol Life Sci. 2007; 64:1679-1700. [PubMed: 17497244]

45. Abedin MJ, Kashio Y, Seki M, Nakamura K, Hirashima M. Potential roles of galectins in myeloid differentiation into three different lineages. J Leukoc Biol. 2003; 73:650-656. [PubMed: 12714580]

46. Camby I, Le Mercier M, Lefranc F, Kiss R. Galectin-1: a small protein with major functions. Glycobiology. 2006; 16:137R-157R.

47. Karmakar S, Stowell SR, Cummings RD, McEver RP. Galectin-1 signaling in leukocytes requires expression of complex-type N-glycans. Glycobiology. 2008; 18:770-778. [PubMed: 18633135]

48. Rabinovich GA, Iglesias MM, Modesti NM, Castagna LF, Wolfenstein-Todel C, et al. Activated rat macrophages produce a galectin-1-like protein that induces apoptosis of T cells: biochemical and functional characterization. J Immunol. 1998; 160:4831-4840. [PubMed: 9590230]

49. Blaser C, Kaufmann M, Muller C, Zimmermann C, Wells V, et al. Beta-galactoside- binding protein secreted by activated T cells inhibits antigen-induced proliferation of T cells. Eur $\mathrm{J}$ Immunol. 1998; 28:2311-2319. [PubMed: 9710209]

50. Baum LG, Seilhamer JJ, Pang M, Levine WB, Beynon D, et al. Synthesis of an endogeneous lectin, galectin-1, by human endothelial cells is up-regulated by endothelial cell activation. Glycoconj J. 1995; 12:63-68. [PubMed: 7795414]

51. Perillo NL, Pace KE, Seilhamer JJ, Baum LG. Apoptosis of T cells mediated by galectin-1. Nature. 1995; 378:736-739. [PubMed: 7501023]

52. Perillo NL, Uittenbogaart CH, Nguyen JT, Baum LG. Galectin-1, an endogenous lectin produced by thymic epithelial cells, induces apoptosis of human thymocytes. J Exp Med. 1997; 185:18511858. [PubMed: 9151710]

53. Liu SD, Whiting CC, Tomassian T, Pang M, Bissel SJ, et al. Endogenous galectin-1 enforces class I-restricted TCR functional fate decisions in thymocytes. Blood. 2008; 112:120-130. [PubMed: 18323414]

54. Toscano MA, Bianco GA, Ilarregui JM, Croci DO, Correale J, et al. Differential glycosylation of TH1, TH2 and TH-17 effector cells selectively regulates susceptibility to cell death. Nat Immunol. 2007; 8:825-834. [PubMed: 17589510]

55. Rabinovich GA, Daly G, Dreja H, Tailor H, Riera CM, et al. Recombinant galectin-1 and its genetic delivery suppress collagen-induced arthritis via T cell apoptosis. J Exp Med. 1999; 190:385-398. [PubMed: 10430627] 
56. Rabinovich GA, Ariel A, Hershkoviz R, Hirabayashi J, Kasai KI, et al. Specific inhibition of T-cell adhesion to extracellular matrix and proinflammatory cytokine secretion by human recombinant galectin-1. Immunology. 1999; 97:100-106. [PubMed: 10447720]

57. van der Leij J, van den Berg A, Blokzijl T, Harms G, van Goor H, et al. Dimeric galectin-1 induces IL-10 production in T-lymphocytes: an important tool in the regulation of the immune response. $\mathrm{J}$ Pathol. 2004; 204:511-518. [PubMed: 15538736]

58. van der Leij J, van den Berg A, Harms G, Eschbach H, Vos H, et al. Strongly enhanced IL-10 production using stable galectin-1 homodimers. Mol Immunol. 2007; 44:506-513. [PubMed: 16581128]

59. Yu X, Siegel R, Roeder RG. Interaction of the B cell-specific transcriptional coactivator OCA-B and galectin-1 and a possible role in regulating BCR-mediated B cell proliferation. J Biol Chem. 2006; 281:15505-15516. [PubMed: 16565088]

60. Rabinovich GA, Sotomayor CE, Riera CM, Bianco I, Correa SG. Evidence of a role for galectin-1 in acute inflammation. Eur J Immunol. 2000; 30:1331-1339. [PubMed: 10820379]

61. Correa SG, Sotomayor CE, Aoki MP, Maldonado CA, Rabinovich GA. Opposite effects of galectin-1 on alternative metabolic pathways of L-arginine in resident, inflammatory, and activated macrophages. Glycobiology. 2003; 13:119-128. [PubMed: 12626408]

62. Toscano MA, Commodaro AG, Ilarregui JM, Bianco GA, Liberman A, et al. Galectin-1 suppresses autoimmune retinal disease by promoting concomitant $\mathrm{Th} 2$ - and $\mathrm{T}$ regulatory-mediated antiinflammatory responses. J Immunol. 2006; 176:6323-6332. [PubMed: 16670344]

63. Levi G, Tarrab-Hazdai R, Teichberg VI. Prevention and therapy with electrolectin of experimental autoimmune myasthenia gravis in rabbits. Eur J Immunol. 1983; 13:500-507. [PubMed: 6861875]

64. Baum LG, Blackall DP, Arias-Magallano S, Nanigian D, Uh SY, et al. Amelioration of graft versus host disease by galectin-1. Clin Immunol. 2003; 109:295-307. [PubMed: 14697744]

65. Offner H, Celnik B, Bringman TS, Casentini-Borocz D, Nedwin GE, et al. Recombinant human beta-galactoside binding lectin suppresses clinical and histological signs of experimental autoimmune encephalomyelitis. J Neuroimmunol. 1990; 28:177-184. [PubMed: 1694534]

66. Santucci L, Fiorucci S, Rubinstein N, Mencarelli A, Palazzetti B, et al. Galectin-1 suppresses experimental colitis in mice. Gastroenterology. 2003; 124:1381-1394. [PubMed: 12730878]

67. Perone MJ, Bertera S, Tawadrous ZS, Shufesky WJ, Piganelli JD, et al. Dendritic cells expressing transgenic galectin-1 delay onset of autoimmune diabetes in mice. J Immunol. 2006; 177:52785289. [PubMed: 17015713]

68. Santucci L, Fiorucci S, Cammilleri F, Servillo G, Federici B, et al. Galectin-1 exerts immunomodulatory and protective effects on concanavalin A-induced hepatitis in mice. Hepatology. 2000; 31:399-406. [PubMed: 10655263]

69. Cooper D, Norling LV, Perretti M. Novel insights into the inhibitory effects of Galectin-1 on neutrophil recruitment under flow. J Leukoc Biol. 2008; 83:1459-1466. [PubMed: 18372340]

70. Iqbal AJ, Cooper D, Vugler A, Gittens BR, Moore A, et al. Endogenous galectin-1 exerts tonic inhibition on experimental arthritis. J Immunol. 2013; 191:171-177. [PubMed: 23720814]

71. Harjacek M, Diaz-Cano S, De Miguel M, Wolfe H, Maldonado CA, et al. Expression of galectins- 1 and -3 correlates with defective mononuclear cell apoptosis in patients with juvenile idiopathic arthritis. J Rheumatol. 2001; 28:1914-1922. [PubMed: 11508600]

72. Ohshima S, Kuchen S, Seemayer CA, Kyburz D, Hirt A, et al. Galectin 3 and its binding protein in rheumatoid arthritis. Arthritis Rheum. 2003; 48:2788-2795. [PubMed: 14558084]

73. Dasuri K, Antonovici M, Chen K, Wong K, Standing K, et al. The synovial proteome: analysis of fibroblast-like synoviocytes. Arthritis Res Ther. 2004; 6:R161-168. [PubMed: 15059280]

74. Xibillé-Friedmann D, Bustos Rivera-Bahena C, Rojas-Serrano J, Burgos-Vargas R, MontielHernández JL. A decrease in galectin-1 (Gal-1) levels correlates with an increase in anti-Gal-1 antibodies at the synovial level in patients with rheumatoid arthritis. Scand J Rheumatol. 2013; 42:102-107. [PubMed: 23244209]

75. Wang CR, Shiau AL, Chen SY, Cheng ZS, Li YT, et al. Intra-articular lentivirus-mediated delivery of galectin-3 shRNA and galectin-1 gene ameliorates collagen-induced arthritis. Gene Ther. 2010; 17:1225-1233. [PubMed: 20520649] 
76. Nishi N, Abe A, Iwaki J, Yoshida H, Itoh A, et al. Functional and structural bases of a cysteine-less mutant as a long-lasting substitute for galectin-1. Glycobiology. 2008; 18:1065-1073. [PubMed: 18796645]

77. Cho M, Cummings RD. Galectin-1, a beta-galactoside-binding lectin in Chinese hamster ovary cells. I. Physical and chemical characterization. J Biol Chem. 1995; 270:5198-5206. [PubMed: 7890630]

78. Huang YJ, Shiau AL, Chen SY, Chen YL, Wang CR, et al. Multivalent structure of galectin-1nanogold complex serves as potential therapeutics for rheumatoid arthritis by enhancing receptor clustering. Eur Cell Mater. 2012; 23:170-181. [PubMed: 22415803]

79. Cedeno-Laurent F, Barthel SR, Opperman MJ, Lee DM, Clark RA, et al. Development of a nascent galectin-1 chimeric molecule for studying the role of leukocyte galectin-1 ligands and immune disease modulation. J Immunol. 2010; 185:4659-4672. [PubMed: 20844192]

80. Dudics V, Kunstár A, Kovács J, Lakatos T, Géher P, et al. Chondrogenic potential of mesenchymal stem cells from patients with rheumatoid arthritis and osteoarthritis: measurements in a microculture system. Cells Tissues Organs. 2009; 189:307-316. [PubMed: 18562787]

81. Dumic J, Dabelic S, Flögel M. Galectin-3: an open-ended story. Biochim Biophys Acta. 2006; 1760:616-635. [PubMed: 16478649]

82. Ochieng J, Furtak V, Lukyanov P. Extracellular functions of galectin-3. Glycoconj J. 2004; 19:527-535. [PubMed: 14758076]

83. Hsu DK, Hammes SR, Kuwabara I, Greene WC, Liu FT. Human T lymphotropic virus-I infection of human T lymphocytes induces expression of the beta-galactoside-binding lectin, galectin-3. Am J Pathol. 1996; 148:1661-1670. [PubMed: 8623933]

84. Kimata H. Enhancement of IgE production in B cells by neutrophils via galectin-3 in IgEassociated atopic eczema/dermatitis syndrome. Int Arch Allergy Immunol. 2002; 128:168-170. [PubMed: 12065918]

85. Jeng KC, Frigeri LG, Liu FT. An endogenous lectin, galectin-3 (epsilon BP/Mac-2), potentiates IL-1 production by human monocytes. Immunol Lett. 1994; 42:113-116. [PubMed: 7890309]

86. Frigeri LG, Zuberi RI, Liu FT. Epsilon BP, a beta-galactoside-binding animal lectin, recognizes IgE receptor (Fc epsilon RI) and activates mast cells. Biochemistry. 1993; 32:7644-7649. [PubMed: 8347574]

87. Zuberi RI, Frigeri LG, Liu FT. Activation of rat basophilic leukemia cells by epsilon BP, an IgEbinding endogenous lectin. Cell Immunol. 1994; 156:1-12. [PubMed: 8200029]

88. Sano H, Hsu DK, Yu L, Apgar JR, Kuwabara I, et al. Human galectin-3 is a novel chemoattractant for monocytes and macrophages. J Immunol. 2000; 165:2156-2164. [PubMed: 10925302]

89. Kuwabara I, Liu FT. Galectin-3 promotes adhesion of human neutrophils to laminin. J Immunol. 1996; 156:3939-3944. [PubMed: 8621934]

90. Kang EH, Moon KC, Lee EY, Lee YJ, Lee EB, et al. Renal expression of galectin-3 in systemic lupus erythematosus patients with nephritis. Lupus. 2009; 18:22-28. [PubMed: 19074165]

91. Lee YJ, Kang SW, Song JK, Park JJ, Bae YD, et al. Serum galectin-3 and galectin-3 binding protein levels in Behçet's disease and their association with disease activity. Clin Exp Rheumatol. 2007; 25:S41-45. [PubMed: 17949550]

92. Taniguchi T, Asano Y, Akamata K, Noda S, Masui Y, et al. Serum levels of galectin-3: possible association with fibrosis, aberrant angiogenesis, and immune activation in patients with systemic sclerosis. J Rheumatol. 2012; 39:539-544. [PubMed: 22247367]

93. Shou J, Bull CM, Li L, Qian HR, Wei T, et al. Identification of blood biomarkers of rheumatoid arthritis by transcript profiling of peripheral blood mononuclear cells from the rat collageninduced arthritis model. Arthritis Res Ther. 2006; 8:R28. [PubMed: 16507131]

94. Forsman H, Islander U, Andréasson E, Andersson A, Onnheim K, et al. Galectin 3 aggravates joint inflammation and destruction in antigen-induced arthritis. Arthritis Rheum. 2011; 63:445-454. [PubMed: 21280000]

95. Neidhart M, Seemayer CA, Hummel KM, Michel BA, Gay RE, et al. Functional characterization of adherent synovial fluid cells in rheumatoid arthritis: destructive potential in vitro and in vivo. Arthritis Rheum. 2003; 48:1873-1880. [PubMed: 12847681] 
96. Li YJ, Kukita A, Teramachi J, Nagata K, Wu Z, et al. A possible suppressive role of galectin-3 in upregulated osteoclastogenesis accompanying adjuvant-induced arthritis in rats. Lab Invest. 2009; 89:26-37. [PubMed: 19015643]

97. Neidhart M, Rethage J, Kuchen S, Künzler P, Crowl RM, et al. Retrotransposable L1 elements expressed in rheumatoid arthritis synovial tissue: association with genomic DNA hypomethylation and influence on gene expression. Arthritis Rheum. 2000; 43:2634-2647. [PubMed: 11145021]

98. Ezzat MH, El-Gammasy TM, Shaheen KY, Osman AO. Elevated production of galectin-3 is correlated with juvenile idiopathic arthritis disease activity, severity, and progression. Int J Rheum Dis. 2011; 14:345-352. [PubMed: 22004231]

99. Hu CY, Chang SK, Wu CS, Tsai WI, Hsu PN. Galectin-3 gene (LGALS3) +292C allele is a genetic predisposition factor for rheumatoid arthritis in Taiwan. Clin Rheumatol. 2011; 30:12271233. [PubMed: 21475983]

100. Neidhart M, Zaucke F, von Knoch R, Jüngel A, Michel BA, et al. Galectin-3 is induced in rheumatoid arthritis synovial fibroblasts after adhesion to cartilage oligomeric matrix protein. Ann Rheum Dis. 2005; 64:419-424. [PubMed: 15345499]

101. Filer A, Bik M, Parsonage GN, Fitton J, Trebilcock E, et al. Galectin 3 induces a distinctive pattern of cytokine and chemokine production in rheumatoid synovial fibroblasts via selective signaling pathways. Arthritis Rheum. 2009; 60:1604-1614. [PubMed: 19479862]

102. Arad U, Angel-Korman A, Amir S, Tzadok S, Seagal O, et al. Knock-down of galectin-3 inhibits spontaneous and lipopolysaccharide-induced IL-6 secretion in fibroblast-like synoviocytes. Arthritis Rheum. 2011; 63(SUPPL 1):10. [PubMed: 20862682]

103. Seki M, Oomizu S, Sakata KM, Sakata A, Arikawa T, et al. Galectin-9 suppresses the generation of Th17, promotes the induction of regulatory T cells, and regulates experimental autoimmune arthritis. Clin Immunol. 2008; 127:78-88. [PubMed: 18282810]

104. Seki M, Sakata KM, Oomizu S, Arikawa T, Sakata A, et al. Beneficial effect of galectin 9 on rheumatoid arthritis by induction of apoptosis of synovial fibroblasts. Arthritis Rheum. 2007; 56:3968-3976. [PubMed: 18050192]

105. Katoh S, Ishii N, Nobumoto A, Takeshita K, Dai SY, et al. Galectin-9 inhibits CD44-hyaluronan interaction and suppresses a murine model of allergic asthma. Am J Respir Crit Care Med. 2007; 176:27-35. [PubMed: 17446336]

106. Tsuchiyama Y, Wada J, Zhang H, Morita Y, Hiragushi K, et al. Efficacy of galectins in the amelioration of nephrotoxic serum nephritis in Wistar Kyoto rats. Kidney Int. 2000; 58:19411952. [PubMed: 11044214]

107. Baba M, Wada J, Eguchi J, Hashimoto I, Okada T, et al. Galectin-9 inhibits glomerular hypertrophy in $\mathrm{db} / \mathrm{db}$ diabetic mice via cell-cycle-dependent mechanisms. J Am Soc Nephrol. 2005; 16:3222-3234. [PubMed: 16177004]

108. Zhu C, Anderson AC, Schubart A, Xiong H, Imitola J, et al. The Tim-3 ligand galectin-9 negatively regulates $\mathrm{T}$ helper type 1 immunity. Nat Immunol. 2005; 6:1245-1252. [PubMed: 16286920]

109. Türeci O, Schmitt H, Fadle N, Pfreundschuh M, Sahin U. Molecular definition of a novel human galectin which is immunogenic in patients with Hodgkin's disease. J Biol Chem. 1997; 272:6416-6422. [PubMed: 9045665]

110. Miyanishi N, Nishi N, Abe H, Kashio Y, Shinonaga R, et al. Carbohydrate-recognition domains of galectin-9 are involved in intermolecular interaction with galectin-9 itself and other members of the galectin family. Glycobiology. 2007; 17:423-432. [PubMed: 17223646]

111. Matsumoto R, Matsumoto H, Seki M, Hata M, Asano Y, et al. Human ecalectin, a variant of human galectin-9, is a novel eosinophil chemoattractant produced by T lymphocytes. J Biol Chem. 1998; 273:16976-16984. [PubMed: 9642261]

112. Asakura H, Kashio Y, Nakamura K, Seki M, Dai S, et al. Selective eosinophil adhesion to fibroblast via IFN-gamma-induced galectin-9. J Immunol. 2002; 169:5912-5918. [PubMed: 12421975]

113. Imaizumi T, Kumagai M, Sasaki N, Kurotaki H, Mori F, et al. Interferon-gamma stimulates the expression of galectin-9 in cultured human endothelial cells. J Leukoc Biol. 2002; 72:486-491. [PubMed: 12223516] 
114. Monney L, Sabatos CA, Gaglia JL, Ryu A, Waldner H, et al. Th1-specific cell surface protein Tim-3 regulates macrophage activation and severity of an autoimmune disease. Nature. 2002; 415:536-541. [PubMed: 11823861]

115. Anderson AC, Anderson DE, Bregoli L, Hastings WD, Kassam N, et al. Promotion of tissue inflammation by the immune receptor Tim-3 expressed on innate immune cells. Science. 2007; 318:1141-1143. [PubMed: 18006747]

116. Wang F, He W, Zhou H, Yuan J, Wu K, et al. The Tim-3 ligand galectin-9 negatively regulates CD8+ alloreactive T cell and prolongs survival of skin graft. Cell Immunol. 2007; 250:68-74. [PubMed: 18353298]

117. Li X, Zhao YQ, Li CW, Yuan FL. T cell immunoglobulin-3 as a new therapeutic target for rheumatoid arthritis. Expert Opin Ther Targets. 2012; 16:1145-1149. [PubMed: 22998573]

118. Arikawa T, Watanabe K, Seki M, Matsukawa A, Oomizu S, et al. Galectin-9 ameliorates immune complex-induced arthritis by regulating Fc gamma R expression on macrophages. Clin Immunol. 2009; 133:382-392. [PubMed: 19800850]

119. Lee J, Oh JM, Hwang JW, Ahn JK, Bae EK, et al. Expression of human TIM-3 and its correlation with disease activity in rheumatoid arthritis. Scand J Rheumatol. 2011; 40:334-340. [PubMed: 21446887]

120. Lee J, Park EJ, Noh JW, Hwang JW, Bae EK, et al. Underexpression of TIM-3 and blunted galectin-9-induced apoptosis of CD4+ T cells in rheumatoid arthritis. Inflammation. 2012; 35:633-637. [PubMed: 21717191]

121. Oka T, Murakami S, Arata Y, Hirabayashi J, Kasai K, et al. Identification and cloning of rat galectin-2: expression is predominantly in epithelial cells of the stomach. Arch Biochem Biophys. 1999; 361:195-201. [PubMed: 9882446]

122. Sturm A, Lensch M, André S, Kaltner H, Wiedenmann B, et al. Human galectin-2: novel inducer of T cell apoptosis with distinct profile of caspase activation. J Immunol. 2004; 173:3825-3837. [PubMed: 15356130]

123. Panoulas VF, Douglas KM, Smith JP, Metsios GS, Elisaf MS, et al. Galectin-2 (LGALS2) $3279 \mathrm{C} / \mathrm{T}$ polymorphism may be independently associated with diastolic blood pressure in patients with rheumatoid arthritis. Clin Exp Hypertens. 2009; 31:93-104. [PubMed: 19330599]

124. Zick Y, Eisenstein M, Goren RA, Hadari YR, Levy Y, et al. Role of galectin-8 as a modulator of cell adhesion and cell growth. Glycoconj J. 2004; 19:517-526. [PubMed: 14758075]

125. Eshkar Sebban L, Ronen D, Levartovsky D, Elkayam O, Caspi D, et al. The involvement of CD44 and its novel ligand galectin-8 in apoptotic regulation of autoimmune inflammation. $\mathrm{J}$ Immunol. 2007; 179:1225-1235. [PubMed: 17617615]

126. Massardo L, Metz C, Pardo E, Mezzano V, Babul M, et al. Autoantibodies against galectin-8: their specificity, association with lymphopenia in systemic lupus erythematosus and detection in rheumatoid arthritis and acute inflammation. Lupus. 2009; 18:539-546. [PubMed: 19395456]

127. Sarter K, Janko C, André S, Muñoz LE, Schorn C, et al. Autoantibodies against galectins are associated with antiphospholipid syndrome in patients with systemic lupus erythematosus. Glycobiology. 2013; 23:12-22. [PubMed: 22887862]

128. Pal Z, Antal P, Srivastava SK, Hullam G, Semsei AF, et al. Non-synonymous single nucleotide polymorphisms in genes for immunoregulatory galectins: association of galectin-8 (F19Y) occurrence with autoimmune diseases in a Caucasian population. Biochim Biophys Acta. 2012; 1820:1512-1518. [PubMed: 22683700] 
(A)

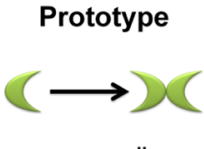

monomer

dimmer

Galectin-1, -2, -5, -7, $-10,-11,-13$, and -14

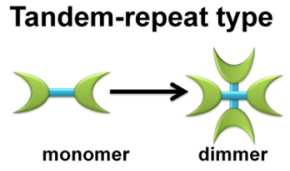

Galectin-4, $-6,-8,-9$, and -12

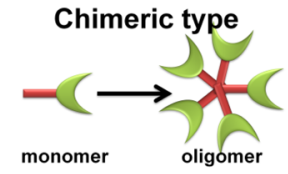

Galectin-3

(B) Cell-ECM interaction Intracellular signaling
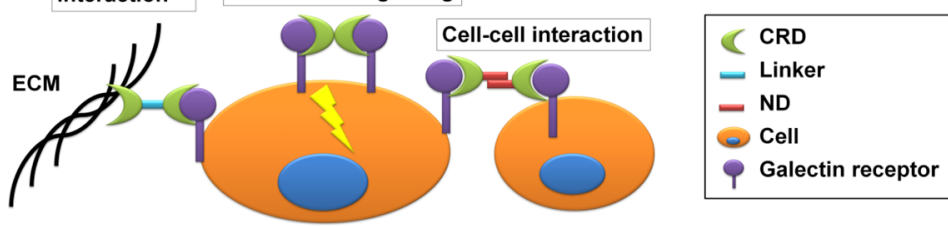

Figure 1. The structure and function of the galectin family members

(A) The galectin family members are divided into three types: the prototype with one carbohydrate recognition domain (CRD), the tandem-repeat type with two CRDs connected by a non-conserved linker, and the chimeric type with one CRD and a non-lectin N-terminal domain (ND). Some galectins can self-associate into dimers or oligomers. (B) Biological functions of extracellular galectins. Bivalent or multivalent galectins crosslink their receptors on the same cell for intracellular signal transduction, two different cells for cellcell interaction, or cell and extracellular matrix (ECM) for cell-ECM interaction. 
Table 1

Pathogenic role and therapeutic potential of galectins in RA.

\begin{tabular}{|c|c|c|c|}
\hline Galectin & Animal studies & Human studies & Therapeutic potential \\
\hline Galectin-1 & $\begin{array}{l}\text { Administration of galectin-1 } \\
\text { suppressed CIA by enhancing T cell } \\
\text { apoptosis and inhibiting IL-2 } \\
\text { secretion [55]. } \\
\text { Galectin-1 limited neutrophil } \\
\text { recruitment to inflammatory tissue } \\
\text { by in vitro experiment and } \\
\text { galectin-1-deficient mice [69]. } \\
\text { Galectin-1 deficient mice were } \\
\text { more susceptible to CIA [70]. }\end{array}$ & $\begin{array}{l}\text { Down-regulated expression of galectin-1 in the } \\
\text { synovial fluid from RA/JIA patients }[71,73,74] \text {. }\end{array}$ & $\begin{array}{l}\text { Administration of galectin-1 or its } \\
\text { derivates ameliorated CIA } \\
\text { [55,75,78,79]. } \\
\text { Galectin-1 induced chondrogenic } \\
\text { differentiation of MSCs from RA } \\
\text { bone marrow }[80] .\end{array}$ \\
\hline Galectin-3 & $\begin{array}{l}\text { Over-expression of galectin-3 was } \\
\text { detected in CIA [93]. } \\
\text { Galectin-3 deficient mice displayed } \\
\text { reduced disease severity of antigen- } \\
\text { induced arthritis [94]. }\end{array}$ & $\begin{array}{l}\text { Increased expression of galectin-3 in sera and } \\
\text { synovial fluid in RA/JIA patients [71,72,91,95- } \\
\text { 97]. } \\
\text { A galectin-3 gene allele (LGALS3 +292C) is more } \\
\text { prevalent in RA patients [99]. } \\
\text { RA patients had a higher number of galectin-3- } \\
\text { expressing FLS [100]. } \\
\text { Galectin-3 induced FLS to secret a set of } \\
\text { proinflammatory cytokines and chemokines [101]. }\end{array}$ & $\begin{array}{l}\text { Intra-articular lentivirus-mediated } \\
\text { delivery of galectin-3 shRNA } \\
\text { ameliorated CIA in rats [75]. } \\
\text { Downregulation of galectin-3 } \\
\text { inhibited IL-6 secretion in FLSs } \\
\text { from RA synovium [102]. }\end{array}$ \\
\hline Galectin-9 & $\begin{array}{l}\text { Galectin-9 deficiency promoted } \\
\text { Th1 and Th17; and inhibited Treg } \\
\text { differentiation, rendering } \\
\text { susceptibility to CIA [103]. } \\
\text { Galectin-9 induced apoptosis of } \\
\text { FLS and downregulated pro- } \\
\text { inflammatory cytokine production } \\
\text { [104]. } \\
\text { Galectin- } 9 \text { ameliorated immune- } \\
\text { complex-induced arthritis by } \\
\text { regulating the expression profile of } \\
\text { macrophage Fc receptors [118] }\end{array}$ & $\begin{array}{l}\text { Galectin-9 induced apoptosis of FLS from RA } \\
\text { patients in cell culture [104]. } \\
\text { Decreased expression of galectin-9 was detected in } \\
\text { RA patients with high disease activities [119]. } \\
\text { Down-regulated expression of Tim-3 led to } \\
\text { defective galectin-9-induced apoptosis of } C D 4^{+} \mathrm{T} \\
\text { cells [120]. }\end{array}$ & $\begin{array}{l}\text { Administration of galectin-9 } \\
\text { ameliorated CIA or immune } \\
\text { complex-induced arthritis } \\
{[104,118] \text {. }}\end{array}$ \\
\hline Galectin-2 & & $\begin{array}{l}\text { Galectin-2 3279C/T gene polymorphism is } \\
\text { correlated with diastolic blood pressure in patients } \\
\text { with RA [123]. }\end{array}$ & \\
\hline Galectin-8 & & $\begin{array}{l}\text { CD44vRA, a CD44 variant prevalent in RA } \\
\text { patients, can neutralize the galectin- } 8 \text { induced } \\
\text { apoptosis of synoviocytes [125]. } \\
\text { Autoantibodies against galectin- } 8 \text { were detected in } \\
\text { the sera of about } 20 \% \text { of RA patients [126,127]. } \\
\text { A galectin-8 gene variant is prevalent in RA } \\
\text { patients and associates with the early onset of RA } \\
\text { [128] }\end{array}$ & \\
\hline
\end{tabular}

